\title{
3. 巨大分子の緩慢な運動
}

\author{
金谷利治 \\ 京都大学化学研究所 \\ 611 京都府宇治市五ヶ庄
}

Key Words: polymers, slow dynamics, neutron spin echo

\section{1.はじめに}

中性子散乱で高分子を高分子として研究する ようになったのは, フランス, グルノーブルの ラウエ・ランジュバン研究所 (Institute LaueLangevin, ILL）が本格的活動を開始した 1970 年代初頭からである。当初は, 高分子科学の興 味としても, また技術的な意味からも, 弾性散 乱, 主に小角中性子散乱実験が多かった。重水 素化ラベル法を用いたバルク中の高分子 1 本鎖 の形態の決定は衝撃的であった1)。今であ小角 散乱測定の重要性は衰えず，その需要はますま す大きくなっている2)。一方, 実験的技術の進 歩や理論の進展により, 中性子非弾性・準弾性 散乱によるダイナミックスの研究にも大きな関 心が寄せられるようになってきた。

図 1 にバルクおよび溶液中の非晶高分子にお いて観測される運動モードの時間と空間スケー ルを模式的に示した。高分子には, 驚くほど広 い空間と時間スケールにその運動モードが存在 するのがわかる。従来, 高分子科学において は, $\mu \mathrm{s}\left(10^{-6}\right)$ 秒よりあ遅い運動に注意が注が れてきた。巨大分子である高分子の特徽が顕著 に現れるのはこのような遅い時間領域だからで ある。しかし, 高分子運動の本質を理解するに は,やはりミクロからメゾスコピック領域での

\footnotetext{
${ }^{\dagger}$ 3. Slow Dynamics of Macromolecules. Toshiji KANAYA: Institute for Chemical Research, Kyoto University, Uji-shi, Kyoto-fu 611, Japan.
}

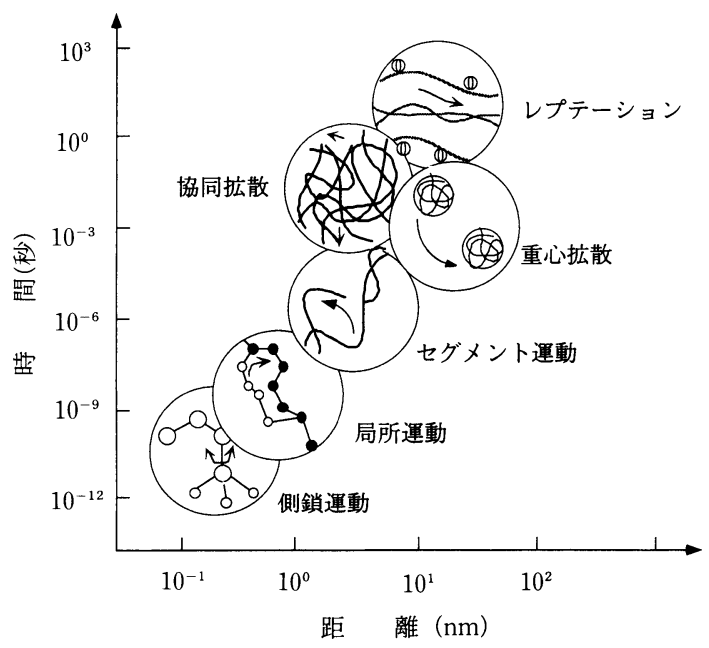

図 1 時間-距離空間におけるアモルファス高分 子の種々の運動モードの模式図

緩和挙動を理解することが不可欠であることが 認識され, 急激に中性子準弾性散乱研究への関 心が高まった。本稿では中性子非弾性・準弾性 散乱により明らかにされてきた高分子のスロー ダイナミックスのいくつかを紹介する。

\section{2. 中性子非弾性・準弾性散乱がカバーする エネルギーと運動量の範囲}

中性子非弾性・準弾性散乱で高分子のスロー ダイナミックスを研究しようとする際に問題と なるのは, 分光器のエネルギー分解能（あしく は時間分解能）である。図 2 に高いエネルギー 分解能を誇る ILL のスピンエコー分光器 (IN 11) および背面散乱型分光器 (IN10, IN13) が力 


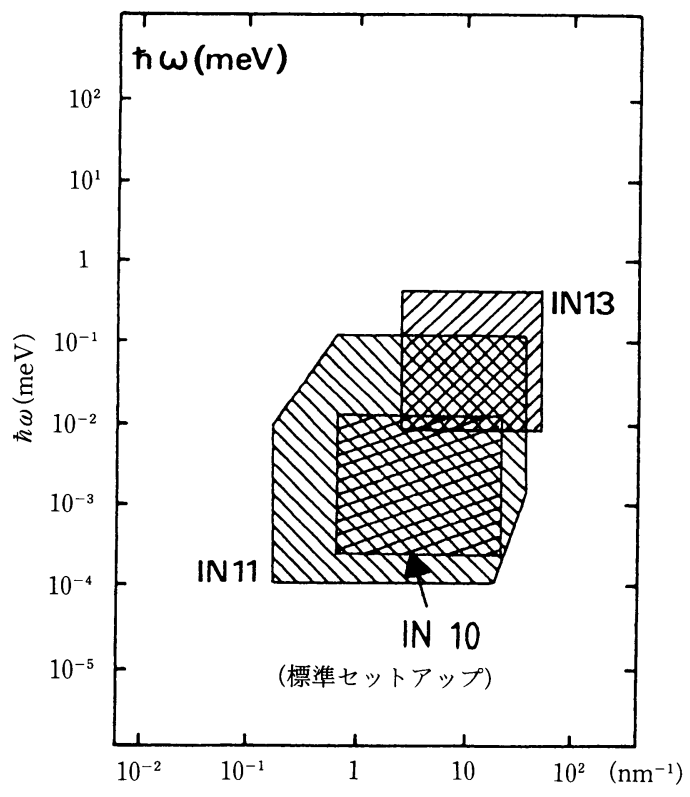

図 2 ILLのスピンエコー分光器 (IN11) およ び背面散乱型分光器 (IN10, IN13) が力 バーするエネルギーと運動量の範囲 $(\hbar \omega$ $Q$ 空間)

バーするエネルギーと運動量の範囲 $(\hbar \omega-Q$ 空 間）を示してある。背面散乱型分光器は周波数 空間で動的散乱則 $S(Q, \omega)$ を観測するのに対 して, スピンエコー分光器は $S(Q, \omega)$ のフー リエ変換である中間散乱関数 $I(Q, t)$ を測定す る。初期のころには, 周波数空間で高分子のス ローダイナミックスを調べることあ多かった が, 最も高い分解能（だいたい数十ナノ秒程 度）を持つスピンエコー分光器の出現以来, 時 間領域での測定が主流を占めている。

\section{3. 希薄溶液中の逜動}

まず，溶液中に高分子鎖が 1 本孤立して浮か んでいる希薄溶液を考えよう。希薄溶液におけ る高分子鎖は二つの特徴的空間スケールにより 規定される。一つは高分子鎖 1 本の広がり（分 子サイズ）を表す回転半径 $R_{\mathrm{g}}$ であり，あう一 つはセグメント長 $l$ である。 $Q<R_{\mathrm{g}}{ }^{-1}$ なる大き な空間スケールで高分子の運動を観测すると高 分子鎖は糸求のように見え, その運動は剛体球
の単純拡散として取り扱える（図 1：重心拡 散)。中性子スピンェコー法により観測される $I(Q, t)$ は

$$
I(Q, t)=\exp (-\Gamma t)
$$

となる。ここで $\Gamma$ は減数定数で, 散乱べクト ル $Q$ と拡散定数 $D$ を用いて $\Gamma=D Q^{2}$ と書ける。 次に, 少し小さな空間スケール, すなわち $R_{\mathrm{g}}{ }^{-1}<Q<l^{-1}$ なる領域で高分子鎖を観测した とする。この領域では, 高分子鎖の全体サイズ $\left(R_{\mathrm{g}}\right)$ あ局所構造も重要ではなく, 高分子鎖は エントロピーバネ（セグメント）でつながれた ビーズのように振舞う（図 1：セグメント運 動)。この際, 流体力学的相互作用を無視した 場合が Rouse モデル（す抜けモデル）であり， 流体力学的相互作用を考慮したのが Zimm モ デル（非す抜けモデル）である。この $Q$ 範囲 における中間散乱関数 $I(Q, t)$ は de Gennes $ら^{4)}$ により計算されており, $\ln [I(Q, t)]$ vs. $t$ の 初期勾配（第一キュムラント） $\Omega$ は, Rouse モ デルに対して

$$
\Omega_{\mathrm{R}}=(0.33 / 4) k T l^{2} Q^{4} / f
$$

Zimm モデルに対して

$$
\Omega_{Z}=(0.0375 \sqrt{2}) k T Q^{3} / \eta
$$

と与えられる。ここで, $f$ は摩擦係数, $\eta$ は溶 媒の粘度である。上式より明らかなように，流 体力学的相互作用が働くかどうかにより，第一 キュムラント $\Omega$ の $Q$ 依存性が $Q^{3}$ から $Q^{4}$ に変 化する。溶液中の高分子鎖の運動にこの流体力 学的相互作用が効いているのかどうかを中性子 スピンエコー法により調べたところ 依存性を示し（図 3 ), 希薄溶液中では流体力 学的相互作用が働き, 高分子鎖は非す抜けの糸 手として溶媒を引き連れて拡散していることが わかった。

$Q>l^{-1}$ の領域に入り, 局所的な構造が支配 的となると，Q〜 $l^{-1}$ 付近で $\Omega$ は $Q^{3}$ 依存性から ずれ始める（図 3 ）。Akcasu ${ }^{6)}$ はこの領域む含 め, $Q<R_{\mathrm{g}}{ }^{-1}$ から $Q>l^{-1}$ までの全 $Q$ 領域で Rouse モデルを用い $\Omega$ を計算し， $Q>l^{-1}$ では $\Omega \sim Q^{2}$ が再び出現することを示した。しかし， 


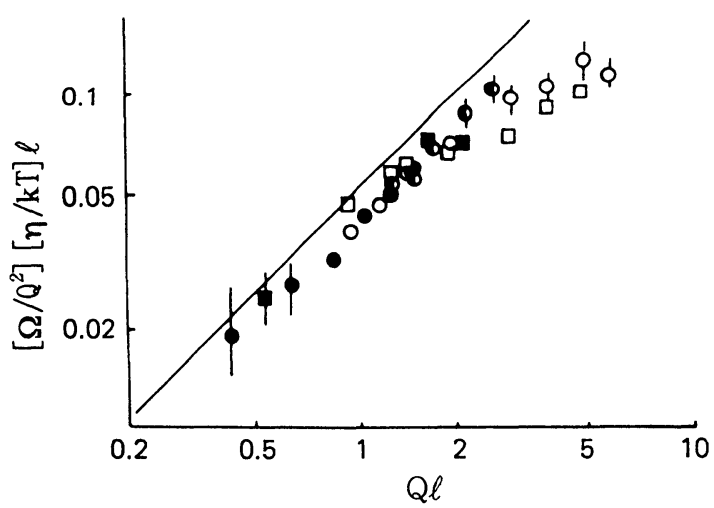

図 3 種々の高分子の $3 \%$ 溶液の規格化した第 1 キュムラント $\Omega / Q^{2}:(\bigcirc) \quad \mathrm{PS} / \mathrm{C}_{6} \mathrm{D}_{6}, 30^{\circ} \mathrm{C}:(\square) \quad \mathrm{PS} /$ $\mathrm{C}_{6} \mathrm{D}_{6}, \quad 70^{\circ} \mathrm{C}$ : (O) $\mathrm{PDMS} / \mathrm{C}_{6} \mathrm{D}_{6}, \quad 30^{\circ} \mathrm{C}$ : (O) PDMS $/ \mathrm{C}_{6} \mathrm{D}_{6}, 70{ }^{\circ} \mathrm{C}:$ (田 PTHF / $\mathrm{C}_{6} \mathrm{D}_{6}, 30^{\circ} \mathrm{C}$ 。実線は $Q^{3}$ 依存性を示す ${ }^{5)}$ 。

この領域で Rouse モデルを採用することに意 味はなく，より局所的は化学構造が効いている と考えるべきである。

\section{4. 㴗厚溶液および溶融状態における運動}

高分子溶液の濃度が増加すると，高分子鎖は 絡み合い始める。この絡み合いのために，高分 子鎖は網目構造を持つゲルのように振舞う（図 1 : 協同拡散運動, $\left.\Omega \sim Q^{2}\right) 。 R_{\mathrm{g}}{ }^{-1}<Q<l^{-1}$ の 領域中の比較的大きな $Q$ 範囲 $Q>\xi^{-1}$ では, 希 薄溶液と同じ単一鎖としての挙動 $\left(\Omega \sim Q^{3}\right.$ あ しくは $\left.\Omega \sim Q^{4}\right)$ が観測されるが， $\left(Q<\xi^{-1}\right)$ で はゲル的な振舞い $\left(\Omega \sim Q^{2}\right)$ が観測される。こ こで, $\xi$ は動的遮蔽長と呼ばれ，分子鎖間相互 作用の範囲の目安である。重水素化ベンゼン中 のポリジメチルシロキサン準濃厚溶液におい て, $\Omega \sim Q^{3}$ から $\Omega \sim Q^{2}$ へのクロスオーバーが 明確に観測され7)，動的遮蔽長 $\xi$ が求められて いる（図 4 ）。高分子濃度がさらに増加すると 流体力学的相互作用は遮蔽され， $Q>\xi^{-1}$ で $\Omega$ 〜 Q4 なる Rouse 挙動が観測される。しかし, Rouse モデルでは周りの分子が摩擦効果を持 つ連続媒体に近似しているため，高分子鎖が絡 み合うことによる運動の拘束を記述することは

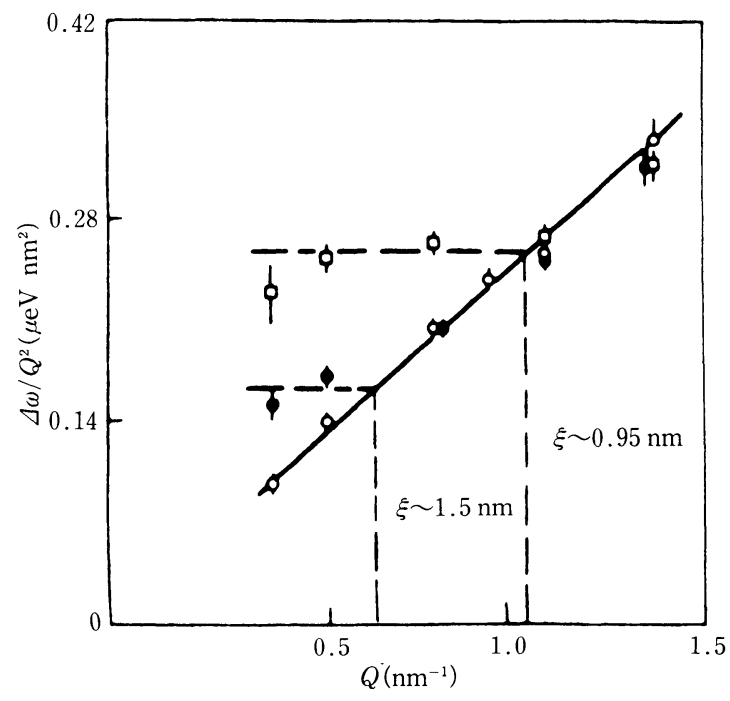

図 4 重水素化ベンゼン中におけるポリジメチ ルシロキサンのスペクトル幅 $\Delta \omega$ の $Q$ 依 存性

(O) $0.05 \mathrm{~g} / \mathrm{cm}^{3}$,

$0.15 \mathrm{~g} / \mathrm{cm}^{3},(\square)$ $0.03 \mathrm{~g} / \mathrm{cm}^{3}{ }^{7)}$ 。

できない。絡み合い効果は, 高分子の粘弾性挙 動を決める最も重要な因子であり，高分子科学 の分野において長い間議論されてきた問題であ る。土井-Edwards による土管理論はこの分野 に著しい進歩をむたらしだ)。

\section{5. レプテーション運動}

高分子鎖が濃厚溶液や溶融状態において動こ うとするとき，周りの鎖との絡み合いのため非 常に動きづらい。それで，高分子鎖は鎖の方向 に沿って蛇のように動くことになる。すると周 りの鎖は動いている鎖に対して土管のような役 割をする(図 1：レプテーション運動)。この ような絡み合い系での分子鎖のダイナミックス を中性子スピンエコー法で調べた結果が図 5 で ある ${ }^{9)}$ 。中間散乱関数は, 時間の短い領域では Rouse モデルの予想により記述できるが，長 時間側では Rouse モデルの予想より遅い減衰 を示し，高分子鎖の運動が絡み合いにより制約 されていることがわかる。実線は絡み合いを考 慮にいれた Ronca モデルであり ${ }^{10)}$ ，良い一致 


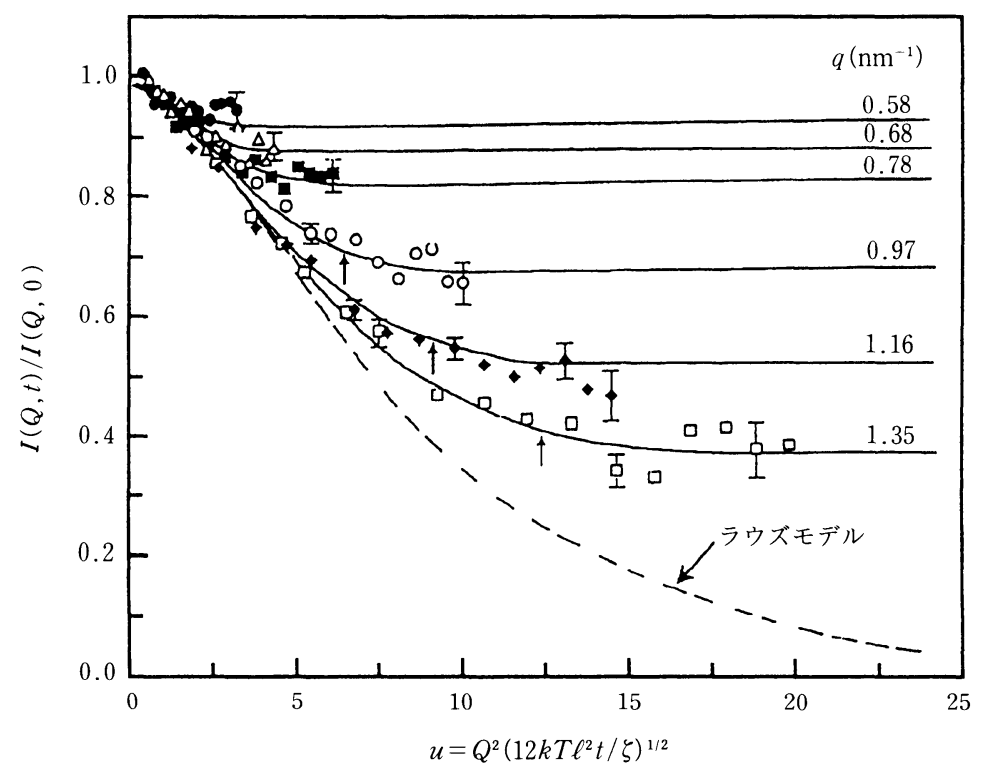

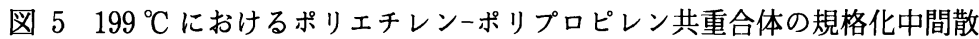
乱関数 $I(Q, t) / I(Q, 0)$

重水素化高分子マトリックスに $10 \%$ の軽水素化高分子が溶けている ${ }^{9)}$ 。 実線はRonca モデルからの予想値 ${ }^{10}$ 。

を示した。中間散乱関数の $Q$ 依存性から評価 した土管の半径は, 粘弾性測定から求めたもの と一致した9)。土井らの土管モデルが微視的測 定より直接的に証明された実験としてその意味 は大きい。

\section{6. その他のスローダイナミックス}

最近は，特種な状況にある高分子の運動も調 べられるようになった。その話題の一つに，高 分子ブラシのダイナミックスがある。溶液中に ある固体表面から高分子鎖が生えている様子を 思い浮かべてあらいたい。これが高分子ブラシ である。固体表面では高分子鎖の密度は高く， 浸透圧のために高分子鎖は広がろう（伸びよ う）とするのに対して，エントロピー弾性は鎖 を収縮させようとするため，呼吸モードが出現

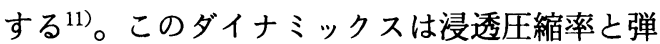
性力の兼ね合いにより決まり，先に述べたよう な流体力学的相互作用も，絡み合いによる拘束 も重要な役割は果たさない。このようなダイナ ミックスが高分子ミセル ${ }^{12)}$ や結晶性ジブロック
共重合体 ${ }^{13)}$ を用いて調べられている。また，必 ずしあ高分子特有というわけではないが，ガラ ス形成高分子 ${ }^{14)}$ のスローダイナミックスやマイ クロエマルジョン15)のスローダイナミックスも 最近の話題である。

\section{文献}

1) Cotton, J. P. et al. : Macromolecules, 7, 864 (1974)

2）松下裕秀: Radioisotopes, 46, 180 (1997) ; 今井 正幸：同上, 46, 186 (1997)

3) The Yellow Book, Guide to Neutron Research Facilities at the ILL, Grenoble, France, 1988

4) de Gennes, P. G. : Physics, 3, 37 (1967); Viollete, E. du B. and de Gennes, P. G. : ibid., 3, 181 (1967)

5) Higgins, J. S. : British Polym. J., 19, 103 (1987)

6) Akcasu, A. Z., Benmouna, M. and Han, C. C : Polymer, 21, 866 (1981)

7) Richter, D., Hayter, J. B., Mezei, F. and Ewen, B : Phys. Rev. Lett., 41, 1484 (1978)

8) Doi, M. and Edwards, S. F : J. Chem. Soc. Faraday II, 74, 1789, 1802, 1818 (1978) 
9) Richter, D., Farago, B., Fetters, L. J., Huang, J. S., Ewen, B. and Lartigue, C : Phys. Rev. Lett., 64, 1389 (1990)

10) Ronca, P. F.: J. Chem. Phys., 79, 1031 (1983)

11) de Gennes, P. G. : C. R. Acad. Sci. Paris Ser. II, 302, 765 (1986)

12) Farago, B., Monkenbusch, M., Richter, D., Huang, J. S., Fetters, L. J. and Gast, A. P : Phys. Rev. Lett., 71, 1015 (1993)
13) Monkenbusch, M., Schneiders, D., Richter, D., Farago, B., Fetters, L. J. and Huang, J. S. : Physica, B213/214, 707 (1995)

14) Frick, B., and Richter, D. : Science, 267, 1939 (1995)

15) Farago, B., Monkenbusch, M., Goecking, K. D., Richter, D. and Huang, J. S. : Physica, B213/214, 712 (1995) 